\title{
The Inspirited Nature of Mindful Curricular Enactment's Community (Re)Making
}

\author{
Margaret Macintyre Latta, Leyton Schnellert, Kim Ondrik \& Murray Sasges
}

\section{Preprint}

Cite as:

Margaret Macintyre Latta, Leyton Schnellert, Kim Ondrik \& Murray Sasges

(2016): The inspirited nature of mindful curricular enactment's community (re)making, Journal of Curriculum Studies, DOI: 10.1080/00220272.2016.1264484 


\title{
The Inspirited Nature of Mindful Curricular Enactment's Community (Re)Making
}

\begin{abstract}
Intertwining case study with practitioner inquiry, a research team seeks language for the conduct of mindful curricular enactment in an alternative public middle school. The school is committed to valuing students' narratives of experience, the resources all bring to the school, and the given particularities of contexts, subject matter, and situations, as the makings comprising learning within and through community. A collaborative approach to inquiry that involves all team partners in the research process and engages the unique strengths that each brings focuses on how this alternative school provides a case for accessing how and why mindful curricular enactment orients accordingly. It is the makings forming this curricular movement, and the room found within these makings to reorganize and reconstruct thinking, that primary attention is oriented towards. Deweyan "roominess" negotiated through such curricular enactment is documented as mindful attention to curriculum-making that fosters the needed room-- the conditions and supports sustaining an individual/collective movement of thinking. Such movement is revealed as necessarily receptive, inciting community (re)making. Its inspirited nature is revealed through participatory modes of being and associated habits embracing knowledge-making as generative, elemental to being human, in need of other(s), assuming temporal/spatial agency, and interdependent with imagination, instilling embodied understandings.
\end{abstract}

Keywords: curricular enactment; mindfulness; community; professional knowledge 


\section{The Inspirited Nature of Mindful Curricular Enactment's Community (Re)Making}

Abandon the notion of subject matter as something fixed and ready-made in itself, outside the child's experience; cease thinking of the child's experience as also something hard and fast; see it as something fluent, embryonic, vital; and we realize that the child and the curriculum...define a single process.

(Dewey, 1902, p.189).

\section{Introduction}

Interactions connecting students' interests with subject matter offer much needed curricular insights for all classrooms. This was Dewey's primary educative concern in The Child and the Curriculum written in 1902. Null (2003), among others, points to the lessons to be learned through attending to Dewey's anti-dualistic stance, seeking curricular balance which values the (inter)play of students' interests and subject matter (p. 68). Our paper explores the curricular terrain of such interplay, turning to the insights of two bold educators and their students, embracing this stance. Attempting to concretely experience, understand, and articulate mindful curricular enactment's lessons, they "abandon the notion of subject matter as something fixed and readymade" in an alternative public middle school context (Dewey, 1902, p. 189). The interactions at play among students' interests and subject matter foster what Aoki (2005) terms "inspirited" curriculum enactment that reclaims the "fullness of body and soul" and unmasks the "texture" of the "lived meanings of teachers and students" (p.357-365). Collectively, as a research team, we can think of no more important 
aim for education than to give the textured curricular terrain encountered, greater visibility and tangibility, gaining "imagery" through "outward manifestation" (Dewey, 1934, p. 278). It is educators' curricular enactment that matters and, yet, worldwide the research literature documents how similar global curricular policies and practices emphasizing compliance and uniformity, very much limit educators' access to curricular terrain that values the interplay of students' interests and subject matter (Day, 2004; Groundwater-Smith \& Mockler, 2009; Kemmis \& Smith, 2008; Korthagen, 2001; Loughran, 2006; Pinar, 2003).

\section{Context}

Formed in Fall 2014, this study explores an alternative public educative setting--V Community School (VCS). Two teachers committed to practicing inquiry-oriented and democratic approaches to education met on the picket line during a teachers' strike. One, the third author of this paper, led a project-based learning centered classroom that emphasized social and emotional learning housed in an elementary school. The fourth author of this paper, taught English and social studies at the neighboring secondary school, taking up local and global service learning. Each felt isolated pursuing social justice oriented goals and curriculum as emergent and co-constructed with students in their respective settings. Together, drawing on the support of a faculty member from the local university (the second author of this paper), they developed a proposal for a school that combined these approaches, comprised of 60 middle school students, that would embrace inquiry learning within and through the local community. VCS was approved by the local school board in January 2014, with 
the condition that it be housed as a program within a secondary school with declining enrollment. Prior to its existence, the two teachers had to promote the opportunity, interview prospective families, and repurpose a large former workshop space to host the 60 students. VCS comprises students, parents, educators, and community mentors all seeking differences in schooling that more fittingly respond to needs and interests.

VCS brings students in grades seven through nine together, though grade levels are not used to define groupings of any kind. Instead, students and educators work alongside each other continually making and remaking a community of learning through mindful curricular enactment. It is the notion of community that permeates the experiential whole at VCS. As Dewey (1910) explains, seeking community "produces community of thought and purpose between the child and the [human] race of which he [sic] is heir" (p. 224). The conceptual underpinnings of community are grounded in the varied ways multiple narratives, perspectives, strengths, and resources hold potential for reframing and reorienting curricular enactment, providing much-needed sustenance for genuine learning opportunities of all kinds (Cajete, 1999; Dewey, 1916; Greene, 1995; Meyer, 2010, Pinar, 2011). The conceptual underpinnings of curriculum assume a Deweyan $(1902,1934,1938)$ operative mode, fostering a continuous reconstructing movement of thinking. Thus, purpose is shaped both individually and collectively as the relational intersections of interests with subject matter manifest. The conceptual underpinnings of mindfulness are grounded in Dewey's (1938) temporal-relational orientation to educating as "an ever-present process" 
(p. 50). This demands that teaching/learning reside mindfully at the nexus of curricular situations and interactions, heightening awareness of the choices educators and students make and their affordances for learning (MacDonald \& Shirley, 2009). And, it is this "very process of living together" that "educates" (Dewey, 1916, p. 6). It is the needed mindfulness within this process, intertwining community within the nature of curriculum, that as educators and researchers we continually confront, negotiate, articulate, and consider. Drawing attention to the given makings of this movement, foregrounds the room found within these makings to reorganize and reconstruct thinking accordingly.

\section{Approach to Inquiry}

VCS is a public alternate middle school, where two educators, two researchers, 60 students, parents, administrators, and local community mentors are collaborating to create and engage in new and valued forms of communitybased curricular enactment. Globally there are calls for such communities of inquiry (see authors, 2012; Biesta, 2007; Groundwater-Smith \& Mockler, 2009; Kemmis \& Smith, 2008; Korthagen, 2001; Loughran, 2006) where researchers and teachers-as-researchers co-develop, study and document this type of curricular enactment (see; Cochran-Smith \& Lytle, 2009; Erickson, et al., 2005). It is our shared interest in co-constructed, living inquiry as mindful pedagogy that has prompted us to turn to community-based research that braids case study (Merriam, 2009) with practitioner inquiry (Cochran-Smith \& Lytle, 2009).

Community-based research involves university-based researchers collaboratively inquiring with practitioners in ways that catalyze community growth across 
learners at all stages of development (students, teachers, faculty). Minkler and Wallerstein (2002) explain:

Community-Based Research is a collaborative approach to research that equitably involves all partners in the research process and recognizes the unique strengths that each brings. CBR begins with a research topic of importance to the community with the aim of combining knowledge and action for social change... (p. 27)

Case study research intertwined with practitioner inquiry as communitybased research rethinks the nature of knowledge and the ways we cultivate and advocate for theory/practice intersections (Edmondson \& Striedieck, 2012; Yendol-Hoppey \& Dana, 2008; Zeichner, 2010) cognizant of contextually sensitive practices (Merriam, 1998; Stake, 2005). Inspired by scholars such as Chambers, Donald, and Hasebe-Ludt (2002) conveying the "braiding of gender, race, language, and place into autobiographical texts" we experience braiding manifesting through individual/collective theorizing informed by the intertwining of multiple data sources. In doing so, we draw from and across fitting theories portraying the experiential features taking shape and finding curricular form (Bowers, 1974; Christou \& Deluca, 2015; Phelan, 2015; Pinar, 1975, Schubert, 1986). Thus, theorizing braids concrete experiences and language, giving expression to the lived learner/learning significances at VCS. We respectfully acknowledge Indigenous ways of knowing that contribute to this notion of braiding (Chambers et al., 2008) and rather than being conceived as a misappropriation, our intent is to provide a medium for sense-making that Donald 
(2012) expresses as "the convergence of wide and diverse influences in an ethically relational manner" (p. 544). Braiding emphasizes for us the strength of relational interplay; fittingly characterizing the curricular making that evolves.

Data collection follows case study methodology and draws from practitioner inquiry. Multiple means are incorporated to gather evidence in relation to our quest for accounts of mindful curricular enactment in action (Merriam, 2009; Stake, 2005). In line with prior community-based research (authors, 2013; Moje, 2000; Villa \& Thousand, 2004), data collection takes into account both individual and social features, including focus groups, individual interviews, classroom artifacts, and extensive field notes. A theorizing record of what is done, explicating how, when, where, and why is shaped throughout the conduct of the inquiry, documenting the case as a whole. Chronicling the lived curriculum over the first year of operation, two teachers and two researchers attend to ongoing field notes that reflect their varying perspectives. Monthly research meetings bring teachers/researchers together to confront, negotiate, articulate, and re-consider this evolving record. Interview data and classroom artifacts further shape the monthly research meetings. Thus, dialogue is a primary means for facilitating and extending the theorizing record. A reflexive approach to data collection and analysis is key, operating both inductively and deductively throughout (Alvesson \& Skoldberg, 2000). Reflexive analysis continually foregrounds the interfaces across the data collected, its interpretations, and the research literature situating the study. These interfaces evolve through configuring description and theory into larger patterns (Nespor, 
2006). The theorizing record discloses the curricular terrain encountered to be patterned again and again by a growing vocabulary by all involved with VCS to voice what learning orients towards, alongside when, how, and why. Heightened sensibilities toward the given particularities of learners/learning and associated capacities to cultivate the needed circumstances for genuine learning contexts are noteworthy. We identify and articulate these interfaces as curricular roominess as we reflect on the unfolding inquiry and our analysis as a whole. Attention now turns to the nature of curricular roominess and ensuing patterns manifesting the needed mindfulness on the part of all participants that strengthens the braid, intertwining community within the nature of curriculum.

\section{Roominess}

Deweyan (1934) "roominess" is characterized as "a chance to be, live, and move" (p. 209). VCS seeks curricular roominess, creating space and time for individual and collective deliberations, intuitions, anticipations, new ideas and enlarged realizations. Provocations form challenges designed by educators and students to act as springboards for inquiry with "roominess" for varied sensemaking paths. Such mindful curricular enactment makes tangible what Dewey (1916) articulates as the play of "the unconscious and the conscious", "process and product", and "the far and the near" (pp. 214-224), inciting the learning significances of doing so for all involved. It is concrete practice with this play "of diverse gifts and interests" (1916, p. 305) that instills community (re)making. But, attending to such curricular interplay entails difficult, complex, provoking, and invigorating learning terrain for all involved. Traversing this curricular terrain is 
the only way its character will manifest and the significances made visible and tangible for all involved. Within this relational intertwining, the interplay of the unconscious/conscience, process/product, and far/near, fosters roominess for thinking that Dewey terms "fruitful" (p. 215). We turn to the lived curriculum, drawing across all data sources to braid narratives of experience that vivify some of the concrete realities entailed in the mindful pursuit of such fruitful thinking.

\section{The Braiding of the Unconscious and Conscience}

From the beginning of VCS in September 2014, its members gather in an opening circle. The circle heightens each person's visibility as they begin to situate themselves in relation to others. After all, though everyone gathers, they do not really know each other. The vulnerable space the circle check-in opens into, becomes a shared experience and daily practice. Facing one another, with each person given the opportunity to express self, a revered presence is cultivated as the space honors each unique individual. Murray, one of the VCS educators, articulates his commitment to circle pedagogy as an integral experience that very much embodies the parts-to-whole relationships key to the community he envisions VCS to become. Murray states:

Everyone breaks out of the equilibrium or status quo. Peers offer different responses and every day you are reminded of these differences. Challenges are encountered daily through the unexpected. And, each person is increasingly drawn into negotiating their relationship to the entire group. (Research Team 
Interview, March 17, 2016)

Circle pedagogy enfolds into the first VCS curricular provocation: a project designed to embrace and strengthen the presence of each individual. Educators explain how students are asked to interrogate themselves, provoked with questions intended to amplify each other's strengths, gifts, talents, limitations, and wounds, suggesting needed conditions for personal growth. One student describes Indian Residential Schools as a deep wound that cut into his connections with his culture as his family continues to grapple with torn relationships and lack of belongingness. In response, another student states, "It's not my problem that my ancestors kidnapped their kids and put them in residential schools. Why are you blaming me? What am I supposed to do about it" (Fieldnotes, Sept. 29, 2014)? These considerations reflect honest, bold, complex statements and questions. Educators do not dismiss, deflect, fear, or admonish these considerations, but, rather, seek ways to challenge and enlarge everyone's understandings. Moving to the floor, seated in the center of the circle the next day, Murray tells the story of abuse that his siblings endured by an individual who was simultaneously astonishingly supportive of him. He recalls his thinking at the time as he moved into the circle:

Community matters to me. I was thinking how do I say to someone that is 13 years old that it ought to matter to all of us. In telling a very difficult personal story I hoped the risk would become a shared 
understanding of the needed safe space for everyone to taking learning risks. (Research Team Interview, March 17, 2016) In a faltering voice Murray articulates how he struggled to understand his siblings' response to his hero and condemned their agitation whenever his 'hero' was around - until the truth was exposed. He recalls how confronting the truth entailed facing what his ethical response ought to be - after all, it didn't happen to him; it wasn't his problem, or fault. Murray reflects on the stillness of the circle:

A quiet and serious tone pervaded the circle. I knew my family story to be a bridge to confront my own responsibility. Thinking about my family as my community and its relationship to responsibility was an awakening for me. I think it became an opening for others to tell their stories. This did not happen necessarily right away, but it seemed to invite emergence and deliberation. (Research Team Interview, March 17, 2016) The circle is absolutely silent throughout the forty-minute narration. All feel the weight of the account. Gradually a few students respond out loud, stating:

Your story is so powerful.

It made me really think.

Thank you for being vulnerable. Thank you for trusting us with your vulnerability.

Because you were so honest, I have decided to tell the story of my Dad's 
death when I present my inquiry. I haven't ever told anyone before. Thank you for inspiring me.

(Fieldnotes, Sept. 29, 2014)

An important opening is seized by educators and acts as a catalyst for continuous confronting of personal values, assumptions, and beliefs in VCS. It is this braiding of unconscious and conscious understandings that manifests as curricular room for self-understandings made explicit, gaining greater consciousness with the heightened awareness and visibility fostering self-scrutiny.

This first curricular provocation evolves into a three-week adventure of shared presentations. Each day finds four unique student personalities to introduce to the community. The offerings are quite formal at the beginning. With time, a spirit of safety slowly emerges in the space itself and within the spaces between each student. Kim, another VCS educator, describes these spaces as cultivating a texture:

The deeper the vulnerability, the deeper the understanding, the deeper the compassion, the deeper the connection. Personal assumptions are faced, at times interrogated, and sometimes shattered. Some students prepare slideshows and in the moment choose instead to improvise. Some bring props. Others perform jumping on the tables and shocking the audience. Some cry. Others laugh. Listening deepens the texture as the days unfold. One student desires not to be afraid to speak his mind anymore. 
Another shares that competition with her older brother shuts her down. Another confesses that he used to stutter. One of the students shares his account regarding his dad leaving for four years. Another student offers her creativity and patience to the world. One voices, "I like to be as laid back as I can. I don't like to get angry. It's embarrassing the next day!" and another expresses, "I always want to know what others are thinking which is obviously impossible. So, it's a weakness" (Fieldnotes, Oct. 2, 2014).

Both educators, Murray and Kim, explain that they notice that relationships with others widen and deepen as the multitude of varying narratives open into the textured space (Research Team Meeting, Nov. 26, 2014 ). The couches and other seating within the space of the classroom become inhabited by different student groupings each morning, with more and more connections building peer relationships. The circle check-in each morning thus becomes more and more meaningful as the room created for sense making is increasingly understood as a shared commitment to situating self in relation to other(s) (Gadamer, 2000; Meyer, 2010). Unconscious understandings are increasingly foregrounded, and their scrutiny and reformulation accepted as forming an ongoing individual/collective learning task.

\section{The Braiding of Learning Processes and Products}

The second curricular provocation, the Burning Question Inquiry, 
envisioned by educators to enable students to frame and follow an inquiry of personal interest, incite internal motivations, and grow learning confidence, becoming a window into how many students lack trust in themselves as learners. It turns out that not all students question their world, or at least raise questions they are willing to share. Of course, there are students who immediately embrace the task. But, a number of students shy away from identifying a question or even from demonstrating any willingness to enter into a conversation with others in pursuit of a question. Educators decide to insist that this project needs to be addressed in pairs or small groups to prompt interactions. The majority of students, though eager to address the inquiry, keep asking for more specifics about the direction the inquiry should take, seeking prescriptions for the content to be learned as well as how the learning ought to be demonstrated. Without these predetermined structures, many students struggle to engage within the ambiguity of following an inquiry through to fruition or even believe that being guided by the inquiry process could possibly constitute learning. Educators recall students' persistent comments such as, "I wish you would teach me something" (Research Team Interview, Oct. 8, 2014). They relay the fear and uncertainty students experience as palatable, and grapple with ways to move students to understand how "education is an opportunity offered, not a service rendered" (Pinar, 2005, p. 5). Seeking the needed learning conditions for all learners is an ongoing task understood by educators, but restoring 
students' natural curiosity seems much more difficult and complex than expected. Kim explains, "As my relationships deepened and understandings of individuals stretched, I began to see that learning was stifled and even blocked when students struggled to keep their inner challenges, and sometimes trauma, silent. The effort must be immense" (Research Team Meeting, Oct. 8, 2014).

Building students' trust in the inquiry process itself entails much educator patience, what Aoki (1992) terms "watchfulness" and "thoughtfulness," attentively waiting and wondering how to proceed, seeking opportunities no matter how small, to move students into being inquirers. Listening caringly to students' considerations and interactions during the inquiry project becomes key to finding ways to productively respond. Educators describe how student inquiry groups take shape gradually, based upon relationships and interests, with cross-curricular queries emerging. These include:

How have fairytales changed over time? How do you define risk?

What is the process of making a simple computer game?

What is the impact of growing up without a Dad?

What is fear and what causes it?

What are the reasons for the Syrian War?

What was the makeup of medieval society?

(Fieldnotes, Oct. 23, 2014) 
Eventually, everyone finds an interesting question and/or a hospitable group. They work for six weeks on this inquiry project, which far exceeds what educators imagined time-wise. But, the ample time gives space to cultivate learners and learning, as well as the documentation and observation of groups, individuals and ensuing dynamics. Three young women, who explore their identities without active fathers in their lives, describe how they fell into this question through talking together and coming to this realization about each other. They also describe how initially the inquiry felt unsure and uneasy. One describes how she felt "somewhat reluctant". Another states that she did not know how important this question was to her until she started to dig into it. They all describe their surprise at the information they found online about the topic and the many ways they could further their inquiry (Fieldnotes, Oct. 30, 2014). As they recognized themselves in the narratives found through the inquiry process itself, their individual and collective commitment to the inquiry grew. They enjoy sharing facts and insights with others and an expertise develops that gives further agency to the shared inquiry. During the formal presentation of their inquiry to the VCS community, the individual/collective pride alongside very personal revelations, are palatable. One of the young women purposefully invites her mother to attend the presentation as a means to communicate experiential understandings with her. Her mother did attend and the importance of her mother being there and hearing/seeing the presentation was an event that 
we surmise held much significance for the young woman. What is clear from the presentation was how each reached new understandings of themselves and internalized these understandings through found language, common narratives of experience, and time and space to synthesize their thinking. After each inquiry is shared, the presenters ask the community, "do you have any questions, comments, feedback and concerns?" When these students shared their inquiry a second time to a group of teacher candidates and one of the researchers, they were asked about the impact of engaging the inquiry. One student, $\mathrm{H}$, shared that she was proud of herself for asking the question; her dad had passed away when she was nine years old. She found confidence and power in investigating and sharing. One teacher candidate replied that she was very brave. $\mathrm{H}$ replied that she had learned a lot and found that she was not the only one in the community growing up without a father. S., another group member replied "our group had the most powerful presentation" of all the inquiry groups. The other girls nodded. She went on to explain that they had become "stronger through this inquiry process" (Fieldnotes, November 26, 2014). Indeed, they had found their voices and this experience propelled an ownership and commitment to their following inquiries. An empowering energy exudes from these young women that was not visible at the beginning of the inquiry.

Burning Question presentations are intentionally spread out over two weeks to encourage and promote thoughtful audience engagement. 
Students are to provide immediate feedback to each group, as well as be prepared to present their learnings about each question at the end of all the presentations. Encouraged to share their findings in the most powerful manner students could imagine to promote engagement and reflect deep learning, presentations range from simulations, to lectures, game shows, films, models, power-points, dramas, and re-enactments. A spirit of kindness and generosity from peers is frequently noted even when a lack of substance or practice is exposed. Questions, comments, feedback and concerns are requested from the audience after each presentation.

Representative examples reveal tentative beginnings into conversations:

You didn't just research how to make a computer game. You actually did it.

Were your sources triangulated? I couldn't tell.

Your presentation was very smooth. I wouldn't change a thing. Having us act out Medieval times was a good idea. It was fun so I learned more.

It was really noisy, but people were engaged.

I found myself asking questions I didn't have before.

I was relaxed and got lost in your stories.

Your voice was really assertive; and I noticed you did most of the talking. Why?

(Fieldnotes, Nov. 6, 2014)

All students are encouraged to think further about questions, 
comments, feedback, and concerns, as they use an assessment continuum to reflect upon process and product for each group. This is an assessment tool designed by educators to emphasize to students the formative nature of learning. But, most groups perceive each other's presentations as being quite developed, recording "promise realized" on the continuums. We wonder if this choice reflects how most students feel vulnerable about their own presentations and the unfamiliar way of demonstrating learning - and, therefore, are less critical and more benevolent. It seems there is little student trust in the growth continuum itself - or, perhaps, how using the continuum might be too revealingpositioning self and others more visibly within this community of learners.

Following the final presentation, the students are given a "test" of the learning they did as a result of the Burning Question presentations. Specifically, each student is asked to address what was learned about each question, the presenters and/or the presentation style. The intention of the "test" is to provide each group with reflective data about how well they helped others learn and grow through their presentations. At the conclusion of the "test", each group is provided with a pile of growth continuums and a stack of learning data. They are asked to attend to the data and note their observations. Students are stunned with how little is learned by others from their presentations. Comments include:

I learned so much from my research. I can't believe that most people only learned one or two things. 
Our presentation was entertaining, but we didn't teach anyone anything.

I don't think the test was fair - only good writers took the time to write down their learnings. Other people were sloppy.

The test was written too long after some of the presentations. I don't have a good memory.

(Fieldnotes, Nov. 13, 2014)

Prompted by the students, these comments lead to many powerful and complicated community conversations. Considerations include:

What is learning?

What is an authentic assessment?

Can you learn something and be able to do it, but not be able to write or talk about it?

How can a presentation be problematic, but learning still happen from it? And yet how can another presentation be pleasant and enjoyable, but no learning happens from it?

Who learns the most from a presentation - the audience or the researchers?

Was learning hidden within this process?

(Fieldnotes, Nov. 20, 2014)

Relational accountability emerges as key to furthering learners and learning. The continual looping of formal and informal feedback by educators, peers, and other community members instills shared 
accountings of learning that position student responses to entail responsibility. The unanticipated questioning of assessment practices and their purposes and relations to learning, reflect the growing awareness of accountability as personal voice and agency within learning. It remains to be seen what will be gleaned as further inquiry cycles transpire. But, it is clear that enabling students to trust themselves as learners is primary, that learning confidence is a function of process/product relation, and that such trust and confidence are fragile and need strengthening (Biesta, 2014; Kessler, 2000; Rodgers \& Raider-Roth, 2006). The braiding of process and product manifests as curricular room for all to cultivate trust in the inquiry process itself is experienced as interdependent within the development of the ensuing learning products.

\section{The Braiding of Far and Near}

Another assessment exercise, designed by educators as a means to synthesize students' understandings of big ideas following group inquiries into colonialism, foregrounds the braiding of far (foreign) and near (familiar) understandings. Asked to draw on examples from the Burning Question presentations, VCS students' articulation of their understandings in response to a question such as, how does the practice of colonialism damage relationships? are read and responded to by peers. For thirty minutes the room falls silent, reflecting a serious, purposeful tone. The use of a growth continuum becomes a thoughtful medium for peer assessment. Students debate with themselves, as each reads and 
provides feedback to a randomly assigned peer. A student comments how she is challenged by the position taken by a peer in response to the question of damaged relationships arising from colonialism. She explains how her peer is wrong, but that the argument he makes is one that is hard to disagree with, as the question is perceived and addressed as a matter of fairness. An excerpt from the initial response to the question is:

I do not get why Indigenous youth are privileged to attend the football game in Vancouver and other special events, over other local youth? (Fieldnotes, April 2, 2015)

The peer assessor enters into conversation with her classmate's thinking as she acknowledges that fairness is the issue being confronted, but that for her, the question under consideration raises questions about the longterm effects of marginalizing some peoples. Neither student is Indigenous. An excerpt is as follows:

I agree that on the surface it does not seem fair. And, I agree that I, too, might want to attend these events. But, I also see how over time the oppression and separation from others has marginalized so many. In VCS, for example, I sometimes feel hurt that needs healing. Maybe that is a way to think about the damage of colonialism? I doubt if attending one sports event will offer healing but it may demonstrate some care and be something they do together that builds something shared that is valued. (Fieldnotes, April 2, 2015) 
The potential suggested from this transaction between students' thinking is "marked by broader awareness and deepening insight into conditions and possibilities" (Hansen, 2011, p. 60) for all involved. It is the terrain encountered within the time and space fostered through the assessment continuum that discloses what Davey (2006) terms "unquiet understandings." These emerge through encounters with ensuing "difficulties", "distances", and "differences" (p. xiv) as VCS participants grapple with far and near understandings through processes of deliberation and debate. Davey juxtaposes far or unquiet understandings with "residing within the quietness of a single interpretation" or near understandings (p. xvi). VCS participants gain concrete practice with multiple interpretations and perspectives, challenging single interpretations and opening time/space for exposing the play of difficulties, distances, and differences. It is practice that in April 2015 (since September, 2014), is now just visibly moving into a community habit or way of being that no longer allows or tolerates deflecting, separating, and discouraging educator/student difficulties, distances, and differences in the world (Dewey, 1934, p. 132). But, it has taken concerted educator and, in turn, student effort to insist upon, cultivate, and sustain the needed practice. Increasingly, VCS engages all involved in navigating near understandings, un-covering and re/presenting underlying values, assumptions, and beliefs, in relation to far understandings, challenging and expanding personal and collective knowing. 
Dewey (1902) emphasizes how dualistic interpretations of self in the world separate the individual from the world. Rather, the play of difficulties, distances, and differences that evolves across VCS students' far and near understandings, offers much substance for continued curricular conversations. The sustenance found through the speculation and projection elicited as the varied student accountings undergirding the question concerning colonialism, surfaces one example. Room is opened to explore these varied perspectival accounts, to consider the human toll of colonialism and ponder why so few know about it, and wonder about the memories elicited for others. Thus, room is opened for many questions that were not in existence before. Tensions arise but educators and students gain practice in accepting and appreciating these tensions as sustaining the learning journey ahead.

Peer involvement in the assessment continuum provides critical insight into the productive far and near tensions at play, exposing what is known and not known, what is said and unsaid, what is visible and invisible. It is the depth of learning potential within this relational play across self and other(s) that is glimpsed through such involvement (Thayer-Bacon, 2003). The student examining her peer's response to the question of colonialism confronts the difference in understandings as wrong and right initially, but begins to consider the reasoning underneath these varying perspectives. In doing so, VCS is reframing learning away from independency, self-sufficiency, mastery, and possession, toward 
cultivating learning agency gained through an inquiring, searching attitude, interdependent with other(s). The braiding of far and near understandings posits alternative thinking, requiring speculation and conjecturing about possibilities. Such braiding fosters continued far and near negotiations on everyone's part, towards acknowledging the complicity of all and the needed care and responsibility toward furthering VCS.

\section{Community $\operatorname{Re}($ Making) as Knowledge Making}

The ongoing organization and reorganization of individual/collective thinking through the negotiation of conscious/unconscious, process/product, and far/near understandings, characterizes the community making and remaking in process. Hansen (2011) describes such community as people "moving closer and closer apart and further and further together" (p.3). VCS students' voices concur and suggest the powers and possibilities. For example, one student explains that when she first considered attending VCS she understood that they would be "out and about in the local community" and that students would have "more say in what and how they took up their learning". She further explains that she did not think that she would have "anywhere near the authority for her own learning" that she actually has experienced. And, she offers her own new definition of community that describes how VCS embodies the continuous reorganizing movement of individual/collective thinking, emphasizing that she "really thought teachers would take over and sort things out as issues arose" and her total amazement that "this is not the case, with students actually having to sort through the messes", issues, and complications (Interview, Jan. 15, 2015). 
Dewey (1916/1944) explains, that it is within the "affections and aversions" of process that connections are made (p. 188). And, it seems the affections and aversions located within the reorganizing movement are inseparably bound up with "seeing large and human significance" (Dewey, p. 24). Granger (2006) calls such significances "our common interests, illuminated through others yet accepting of otherness, in the objects and events of our protean commonplace world-our common wealth" (p. 275). It is such wealth that is being made accessible at VCS.

Accessing it entails active engagement with the thinking of others, traversing the conscious and unconscious, process and product, and far and near as VCS community members move closer and closer apart and further and further together. Its inspirited nature is revealed through participatory modes of being and associated habits embracing knowledge-making as generative, elemental to being human, in need of other(s), assuming temporal/spatial agency, and interdependent with imagination, instilling embodied understandings.

It is preoccupation with suppressing the moving curricular terrain of the conscious and unconscious, process and product, and far and near that Davey (2006) explains, "masks a failure (or a fear) to confront the risks of what it is to be merely human" (p. 22). At VCS we are reminded of how 1) the questioning and scrutinizing involved in attending to these risks needs room to form through time and space for conscious/unconscious sense-making; 2) the analyzing, discerning, and reflecting involved in attending to these risks needs room to form 
through time and space to purposefully articulate processes in relation to products; and, 3) the speculating, adapting, changing, and building involved in attending to these risks needs room to form through time and space to negotiate between near and far understandings. It is only through elucidating the curricular terrain afforded, intersecting curriculum and community with each individual, that insights into the necessary mindful habits for educators and their students to inhabit become ways of being. Dewey's (1916/1944) stance on the nature of knowledge is a key underlying assumption. He explains, how knowledge "never can be learned by itself; it is not information, but a mode of intellectual practice, a habitual disposition of the mind (p. 188). Such a mode and associated habits, takes a "practiced receptivity" (Davey, 2006, p. 66). It is a receptivity that is not instrumental or applied but must be practiced to see with and act on the possibilities. Capacities to draw connections across particular learning experiences and realities, to converse meaningfully with other(s), and build and articulate defensible understandings, must be actively enacted and brought into being. Traversing such knowledge-making terrain at VCS manifests its inspirited nature. This inspiritness is increasingly revealed through participatory modes of being and associated habits embracing knowledge-making as generative, elemental to being human, in need of other(s), assuming temporal/spatial agency, and interdependent with imagination, instilling embodied understandings. 


\section{Knowledge-Making as Generative}

Educators attend to the terrain of knowledge-making with their students, continually seeking attunement within the specifics of inquiry itself. Suggestions unfold and possibilities are negotiated, as paths of inquiry open up. Attending to what Dewey (1938) terms the "powers and purposes of those taught" (p. 45) forms and informs the materials for knowledge-making. As students share their histories, beliefs, strengths, and desires, the thinking that emerges respects and reflects these given contributions. Not to do so, as Dewey points out would be "to neglect the place of intelligence in the development and control of a living and moving experience" (p. 88). The powers and purposes take multiple forms, but revering and conversing with these as the materials for knowledge-making is the necessary starting place at VCS towards authoring inquiry. It is a willingness to enter and dwell within the relationships present and already at play, that the generative process of knowledge-making invites. It is within the apprehension of these relationships that all involved can create and find meanings.

\section{Knowledge-Making as Inherently Human}

Educators attend to the historical, social, political, personal, and cultural experiences, traditions, and contexts that influence and interact within every situation, foregrounding these as the relational complexities human beings bring to all knowledge-making. Dewey (1910/1997) clarifies, “...one can teach others to think only in the sense of appealing to and fostering 
powers already active in them" (p. 30). He identifies curiosity, suggestion, and order-making as elemental human resources holding the genesis for inquiry of all kinds. Accessing the powers within these resources at VCS draws all involved into interactions with given relational complexities, revealing the potentialities these elemental resources hold for varied directions inquiries may take. Authorizing such inquiries, manifests knowledge-making through following up and linking together individual/collective connections.

\section{Knowledge-Making as Needing Other(s)}

Educators attend to the ways in which other(s) calls personal understandings into question, valuing interactions, debates, and deliberations as always in need of other ideas, experiences, perspectives, and understandings. Dewey (1934) describes the knowledge-making ground encountered to begin with impulsion, acknowledging interdependency of self with surroundings, learning through resistance and obstacles, and unfolding at the junctures of old and new experiences (pp. 58-60). Personal needs and interests initially direct efforts. These efforts are then redirected as individuals convey and begin to attend to the relations each meet and negotiate, as thinking with and through others is made more accessible. Understandings are reached and extended at the conjunctures of the old and the new. The evolving authorized inquiries at VCS are not simply the workings of an individual's interiority, but rather, purposefully inclusive of the narratives and reflections of others. 


\section{Knowledge-Making as Temporal/Spatial Agency}

Educators attend to the temporality, the past-present-future interplay within every situation, responding to the relational and interactive connections that ensue through inquiry. These connections hold the contingencies that educators must embrace as the risks and opportunities worthy of negotiation. Dewey (1938) explains that it is the sustenance gained through such embrace that occasion the kind of present that "has a favourable effect upon the future" (Dewey, p. 50). Connections attending to the present's potential invest in individual/collective growth at VCS.

Dewey (1938) explains how growth's organization is dynamic, needing both space and time, structured to bring the present's potential to immediate attention.

\section{Knowledge-Making as Interdependent with Imagination, Instilling Embodied Understandings}

Educators attend to imagination as a gateway to knowledge-making, acting with a capacity to see with potential in situations, self, and other(s), rather than a distinct specialized faculty of the mind. Imaging forth ideas via deliberations, intuitions, anticipations, and enlarged realizations invigorates inquiry at VCS. It is Dewey's (1934) claim that such participatory knowledge-making through thinking, feeling, seeing, and acting "illuminates" (p. 22) understandings and fosters internalization, instilling embodied comprehension. ${ }^{1}$ 
The important role of educators' concrete practice within community (re)making cannot be underestimated. "Our way of being in the world of the classroom - whether we are "being peace" or "being impatience," "being respect" or "being condescension," "being awareness" or "being numb" - will ultimately determine how safe and open students will feel when we invite them to explore deep matters" (Kessler, 2000). Educators need to spend time engaging in making and remaking to locate the curricular conditions, practices, and possibilities, and also, instill the "open, vulnerable, and in question" (Davey, 2006, p. 17) inhabitants, necessary for residing well within the makings of community. The primary concern is for learner-learning connectedness, mediated in relationship to other(s). Seeking such connectedness means educators and students must invest in creating and sustaining a movement of thinking that belongs to the self and situation concerned. Therefore, connectedness is mindful of the histories and particularities of individuals and situations, attending to the moving character of the curricular circumstances in which they find themselves. Active reorganizing on a continual basis insists on genuine concerted action on the parts of educators and students, oriented toward multiplicity and purposefulness, manifested through divergent learning processes and products. The reorganizing movement fosters room for learner confidence and growth, alongside respect and value for differences of all kinds as catalysts in coming to know self and others. The reorganizing movement finds its own learning pace, generated through personal involvement, questioning what is encountered as topics open up and unfold. Thus, the reorganizing movement is concerned with 
emergence and development, with interaction, deliberation, debate, prudence, and judgments made within process, as expected participatory practices. At VCS, we are increasingly aware that community making and remaking allows for the developmental, unfolding process of self-formation and discovery in relation to the world. The braiding of unconscious and conscious understandings with learning processes and products, and far and near sense-making, gives life inspiriting learning and enabling students to situate themselves in, of, and for the world (Hansen, 2011).

\section{In Conclusion}

Insisting on curricular room to attend to the modes and habits of mindful curricular enactment at VCS, unmasks its complex, relational character. Dewey (1902/1990) describes the tendencies to orient away from such complicated curricular conversations to be "evils," positioning the child versus the curriculum (p.202). These evils disregard organic connections between self and the world (from which we derive "content"), thus, "there is no craving, no need, no demand" or internal motivation, and opportunities for experiencing "self-reasoning powers" and the potentially "thought provoking character" of curriculum is obscured ( $p$. 204). Traces of these evils are present, tangible, and trouble the makings of VCS. Educators persist, orienting away from such evils, fostering the needed curricular "roominess". In doing so, they explore the braids these complicated curricular conversations can take with their students. The thought provoking character of such curricular conversations conveys an "inspirited" nature, relaying Aoki's (1991) characterization of curricular enactment as teachers, alongside 
students, dwell in the midst of curriculum-making. VCS educators dwell in the midst, seeking the necessary conditions and fostering the associated supports, experiencing with their students the lived curricular consequences of complicated conversations. Inspirited curriculum-making through adapting, changing, building meaning reflects identities in the making in relation with community in the making. This inspirited nature characterizing the curricular movement of thinking reclaims Aoki's (2005) fullness of body and soul, unmasking the textured meanings of teachers and students. In year two at VCS curriculum making's powers and possibilities are now just visibly moving into habits and ways of being that attend to educator/student difficulties, distances, and differences in the world (Dewey, 1934). But, it has taken much practice, challenging and expanding personal and collective knowing.

Practice, specifically, lack of curricular practice with inspirited curricular enactment for educators and their students is a persistent, troubling concern given global preoccupation with suppressing such curricular terrain (Groundwater-Smith \& Mockler, 2009). But, VCS educators and students reveal the questioning, scrutinizing, analyzing, discerning, reflecting, speculating, adapting, changing, and building selves, inspiriting the discourse within curriculum-making that must be enacted to gain the needed "practiced receptivity" (Davey, 2006). That is why, akin to Hansen (2011) the primacy of educators' roles is clear, and the conditions, supports, and resources to enable such lived curricular understandings towards a practiced receptivity, are a necessity. Hansen places educators in a catalytic role of concomitantly seeking 
and acting to further learning about self and the world. He draws attention to the conjunction "and" as the formative terrain where educators must reside, attend, create, and sustain curricular experiences that put students in ongoing contact and communication with play across self and other(s). At VCS we document this interplay as braiding, entailing mindful modes of being embodying associated habits that form the theorizing ground for heightening attention to ongoing decision-making for learners' and learning's sakes. Such terrain positions all involved to learn about other(s) and in turn self, creating and concomitantly being created, nurturing the movement of thinking within community making and remaking (Meyer, 2010). The boldness to journey into this formative, curricular terrain, navigating differences as productive and generative, cultivating a community sustained through differences alongside collaborative engagement, thus grappling with the ensuing "complicated curricular conversations" (Pinar, 2009, p.11), forms mindful curricular enactment's tasks that must be continuously practiced. The impacts that are being documented at VCS extend far beyond the immediacies of the classroom into long-term understandings of what constitutes education, curriculum, and community. Dewey's (1902) realization that the child and the curriculum constitute a single process are recalled again and again, revealing learning as roomy paths of self-formation and discovery that braid significances definitely worth investing within. 


\section{References}

Alvesson,M. \& Skoldberg, K. (2000) Reflexive Methodology (London: SAGE Publications).

Aoki, T. (1992) Layered voices of teaching. In W. Pinar \& W. Reynolds (eds), Understanding Curriculum as Phenomenological and Deconstructed Text. (New York, NY: Teachers College Press),17-27.

Authors $(2012,2013,2015)$

Biesta, G. (2007) Why "what works" won't work: Evidence-based practice and the democratic deficit of educational research. Educational Theory, 57 (1), 122.

Biesta, G. (2014) The Beautiful Risk of Education (Boulder, CO: Paradigm Publishers).

Bowers, C. A. (1974) Cultural Literacy for Freedom: An Existential Perspective on Teaching, Curriculum, and School Policy (Eugene, Oregon: Elan Books).

Cajete, G. (1999) Look to the Mountain: An Ecology of Indigenous Education (Skyland, NC: Kivaki Press).

Chambers, C., Hasebe-Ludt, E., Donald, D., Hurren, W., Leggo, C., \& Oberg, A. (2008) Metissage. In A. Coles and J. Knowles (eds.) Handbook of the Arts in Qualitative Research: Perspectives, Methodologies, Examples, and Issues (Thousand Oaks, CA: Sage), 141-153. 
Chambers, C., Donald, D., \& Hasebe-Ludt, E. (2992) Creating a curriculum of metissage. Insights, 7 (2). Retrieved from http://einsights.ogpr.educ.ubc.ca/v07n02/metissage/metiscript.html

Christou, T. \& Deluca, C. (2015) The curriculum theorizing of teacher education. Journal of the Canadian Association for Curriculum Studies, 13 (1), 1-4.

Cochran-Smith, M., Feiman-Nemser, S., McIntyre, D. J., \& Demers, K. E. (2008) (eds) Handbook of Research on Teacher Education (New York, NY: Routledge).

Cochran-Smith, M. \& Lytle, S.L. (2009) Inquiry as Stance: Practitioner Research for the Next Generation (New York, NY: Teachers College Press).

Davey, N. (2006) Unquiet Understanding: Gadamer's Philosophical Hermeneutics (New York: State University of New York Press).

Day, C. (2004) A Passion for Teaching (New York, NY: Routledge).

Dana, N. F. \& Yendol-Hoppey, D. (2014) The Reflective Educator's Guide to Classroom Research: Learning to Teach and Teaching to Learn through Practitioner Inquiry, 3rd Edition (Thousand Oaks, California: Corwin Press).

Dewey, J. (1902/1990) The Child and the Curriculum (Chicago, IL: The University of Chicago Press).

Dewey, J. (1910/1997) How We Think (New York, NY: Dover).

Dewey, J. (1916/1944) Democracy and Education (New York, NY: Free Press).

Dewey, J. (1934) Art as Experience (New York, NY: Capricorn Books).

Dewey, J. (1938) Experience and Education (New York, NY: Touchstone). 
Donald, D. (2012) Indigenous metissage: A decolonizing research sensibility, International Journal of Qualitative Studies in Education, 25 (5), 533-333.

Edmondson, J. \& Striedieck, I. (2012) Intentional teacher education: The education of scholarly practitioners. In M. Macintyre Latta \& S. Wunder (eds.), Placing Practitioner Knowledge at the Centre of Teacher Education: Rethinking the Policies and Practices of the Education Doctorate (Charlotte, NC: IAP Publishing), 249-260.

Erickson, G., Mitchell, I., Minnes-Brandes, G. \& Mitchell, J. (2005) Collaborative teacher learning: Findings from two professional development projects. Teaching and Teacher Education, 21(7), 787-798.

Gadamer, H. G. (2000) Truth and Method (New York, NY: Contiuum).

Greene, M. (1995) Releasing the Imagination: Essays on Education, the Arts, and Social Change (San Francisco, CA: Jossey-Bass).

Granger, D. A. (2006) John Dewey, Robert Persig, and the Art of Living: Revisioning Aesthetic Education (New York, NY: Palgrave Macmillan).

Groundwater-Smith, S. \& Mockler, N. (2009) Teacher Professional Learning in an Age of Compliance (UK: Springer).

Hansen, D. T. (2011) The Teacher and the World: A Study of Cosmopolitanism as Education (New York, NY: Routledge).

Kemmis, S., \& Smith, T. J. (2008) Enabling Praxis: Challenges for Educators (Rotterdam: Sense). 
Kessels, J. P. A. M. \& Korthagen, F. A. J. (1996) The relationship between theory and practice: Back to the classics. Educational Researcher, 25 (3), 17-22.

Kessler, R. (2000) The Soul of Education: Helping Students find Connection, Compassion, and Character at School (Alexandria, VA: Association for Supervision and Curriculum Development).

Korthagen, F. (2001) Linking Practice and Theory: The Pedagogy of Realistic Teacher Education (Mahwah, NJ: Lawrence Erlbaum).

Loughran, J. (2006) Developing a Pedagogy of Teacher Education:

Understanding Teaching and Learning about Teaching (New York, NY: Routledge).

MacDonald, E. \& Shirley, D. (2009) The Mindful Teacher (New York: Teachers College Press).

Merriam, S. B. (1998) Qualitative Research and Case Study Applications in Education. San Francisco: Jossey-Bass Publishers.

Meriam, S. B. (2009) Qualitative Research: A Guide to Design and Implementation (San Francisco, CA: Jossey-Bass).

Meyer, K. (2010) Living inquiry: Me, myself, and other. Journal of Curriculum Theorizing, 26(1), 85-96.

Minkler M., \& Wallerstein N. (2002) Community-based Participatory Research for Health: From Process to Outcomes (San Francisco CA: Jossey Bass Publishers).

Moje, E. B. (2000) Circles of kinship, friendship, position, and power: Examining the community in community-based literacy research. Journal of Literacy 
Research, 32, 77-112.

Nespor, J. (2006). Finding patterns with field notes. In Green, J., Camilli, G., \& Elmore,P. (eds.), Complementary Methods for Research in Education (pp. 587-598). Washington, DC: American Educational Research Association.

Null, J. W. (2003) John Dewey's child and the curriculum 100 years later: Lessons for today? American Educational History Journal, 30, 59-68.

Phelan, A. (2015). Curriculum Theorizing and Teacher Education (New York: Routledge).

Pinar, W. F. (1975) Currere: Toward reconceptualization. In W. F. Pinar (ed), Curriculum Theorizing: The Reconceptualists (Berkeley, CA: McCutchan Publishing).

Pinar, W. F. (2003) (Ed.) International Handbook of Curriculum Research. New Jersey: Lawrence Earlbaum.

Pinar, W. F. (2009) The Worldliness of a Cosmopolitan Education: Passionate Lives in Public Education (New York: Routledge).

Pinar, W. F. (2011) The Character of Curriculum Studies: Bildung, Currere, and the Recurring Question of the Subject (New York: Palgrave Macmillan).

Pinar, W. F. \& Irwin, R. L. (2005) (eds). Curriculum in a new key: The collected works of Ted. T. Aoki. New Jersey: Lawrence Earlbaum.

Ritchhart, R. \& Perkins, D. N. (2000) Life in the mindful classroom: Nurturing the disposition of mindfulness. Journal of Social Issues, 56 (1). 27-47.

Rodgers, C. R. \& Raider-Roth, M. B. (2006) Presence in teaching. Teachers and Teaching: Theory and Practice, 12 (3), 265-287. 
Schubert, W. H. (1986) Curriulum: Perspective, Paradigm, and Possiblity (New York: Macmillan Publishing).

Stake, R. (2005) Qualitative case studies, In N. Denzin and Y. Lincoln (eds), The Sage Handbook of Qualitative Research, Third Edition (Thousand Oaks, CA: Sage), 443-466.

Thayer-Bacon, B. J. (2003) Relational Epistemologies (New York: Peter Lang).

Villa, L. J. \& Thousand, J.S. (2004) Collaboration, co-teaching, and differentiated instruction: A process-oriented approach to whole schooling. International Journal of Whole Schooling 1 (1), 13-27.

Zeichner, K. (2010). Rethinking the connections between campus courses and field experiences in college-and university-based teacher education. Journal of Teacher Education, 61 (1-2), 89-99.

${ }^{1}$ For a more substantive discussion of knowledge-making modes of being and habits see: (Author, 2013) 